\title{
Penile Sarcoidosis: A Rare Initial Manifestation
}

\section{Penil Sarkoidoz: Nadir IIk Tutulum}

Sibel Doruk', Eyüp Sabri Uçan², Faruk Doğan ${ }^{3}$, Funda Taşılı, Hasan Umut Kantarcı ${ }^{5}$, Gülistan Karadeniz' Kemal Can Tertemiz ${ }^{2}$

\section{Abstract}

Sarcoidosis is a multi-systemic disease and genitourinary involvement is rarely seen. Penile involvement is even rarer among genitourinary sarcoidosis. In this article, we present two cases of penile sarcoidosis. The first case was admitted to our urology clinic with penile itching and pain and his symptoms did not improve with non-specific antibiotic therapy. In biopsy, non-caseified granulomatous inflammation was detected. He did not have any systemic and pulmonary compliant. The second case was admitted to our urology clinic with penile nodules and nodules were excised for diagnosis. In dermis biopsy, multiple multi-nuclear giant cells and granulomas were detected. He had shortness of breath, wheezing, and sweating. $\mathrm{He}$ was treated with systemic prednisolone. Both cases were successfully treated with pharmacological treatments.

Key words: : Sarcoidosis, genitourinary sarcoidosis, penile sarcoidosis.

\section{Özet}

Sarkoidozis genitoüriner sistemin nadiren tutulduğu sistemik bir hastalıktır ve penis tutulumu ise genitoüriner sarkoidoz olguları arasında çok daha nadir görülür. Bu makalede penis sarkoidozu tanısı konulan ve takip edilen iki olgu literatür eşiliğinde sunulmuştur. Illk olgu üroloji kliniğine peniste kaşıntı ve ağrı yakınması ile başvurmuştu ve bu yakınmaları nonspesifik antibiyotik tedavi ile gerilememişti. Biyopside nonkazifiye granülomatöz inflamasyon izlendi. Herhangi bir sistemik ve solunumsal yakınması yoktu. Lokal kortikosteroid tedavi verildi. İkinci olgu da üroloji kliniğine peniste nodül yakınması ile başvurmuştu ve nodül eksize edilmişti. Biyopsi örneğinde dermisde multinukleer dev hücreler ve granülomlar izlendi. Nefes darlığı, hırıltı ve terleme yakınması olan hastaya sistemik prednizolon tedavisi başlandı. İki olgunun da yakınmaları uygulanan bu tedaviler ile düzeldi.

Anahtar Sözcükler: Sarkoidoz, genitouriner sarkoidoz, penis sarkoidozu.
Sarcoidosis is a multi-systemic disease, characterized by non-caseified granulomatous inflammation. In particular, mediastinal lymph nodes, lungs, skin, eyes, and liver are the most affected organs (1). Genitourinary system involvement is very rare
(0.2\%). In 1936, the first case of testicular sarcoidosis was published by Schaumann and, then, the other genitourinary organs involvements such as prostate, epididymis, penis, scrotum, and spermatic cord have been reported (2).

'Şifa Üniversitesi, Göğüs Hastalıkları Anabilim Dalı, İzmir

2Dokuz Eylül Üniversitesi, Göğüs Hastalıkları Anabilim Dalı, İmir

${ }^{3}$ Şifa Üniversitesi, Üroloji Anabilim Dalı, İzmir

${ }^{4}$ Sifa Üniversitesi, Patoloji Anabilim Dalı, İzmir

${ }^{5}$ Şifa Üniversitesi, Radyoloji Anabilim Dalı, İzmir

2Department of Pulmonary Medicine, Dokuz Eylül University, izmir,

Turkey

${ }^{3}$ Department of Urology, Şifa University, İzmir, Turkey

${ }^{4}$ Department of Pathology, Şifa University, İmir, Turkey

${ }^{5}$ Department of Radiology, Sifa University, İmir, Turkey

Submitted (Başvuru tarihi): 26.08.2015 Accepted (Kabul tarihi): 21.01.2016

Correspondence (iletişim): Sibel Doruk, Department of Pulmonary Medicine, Şifa University, İzmir, Turkey

e-mail: sibelsahbaz@yahoo.com 


\section{CASE}

Case 1: A 31 -year-old male was admitted to our urology clinic with of penile itching and pain for two weeks. Physical examination revealed penile erythema and swelling. The patient was treated with sulbactam-ampicillin for 14 days; however, his symptoms did not improve with this therapy. In further examination, three nodules were detected (two nodules were approximately $1 \mathrm{~cm}$ in-size in the dorsal penis and other nodule was approximately 2 $\mathrm{cm}$ in the ventral penis) and these nodules were excised. In biopsy, non-caseified granulomatous inflammation was detected (Figure 1 and 2). The patient was admitted to the pulmonary medicine outpatient clinic with a preliminary diagnosis of sarcoidosis. The patient had no systemic complaints and also he did not define any symptom suggesting nephrolithiasis, erythema nodosum, uveitis or arthritis. His physical examination findings were normal. Routine biochemical analysis, urine analysis, erythrocyte sedimentation rate, and abdominal ultrasonography were normal. Several perihilar lymphadenopathy, which was the largest diameter as $3 \mathrm{~cm}$ and several pulmonary milimetric nodules, which were the largest diameter as 7 $\mathrm{mm}$ were detected in thoracic computed tomography (Figure 3 and 4). Pulmonary function test (PFT) results were normal [FEV1/FVC: \%80, FEV1: 4.98 L (114\%), FVC: 6.23 L (1 19\%), PEF: 8.23L (83\%), FEF25-75: 5.23L (108\%)]. Tuberculin skin test was non-reactive and serum angiotensin converting enzyme (ACE) level was $102 \mathrm{U} / \mathrm{L}$ (elevated). He was treated with local corticosteroid therapy.

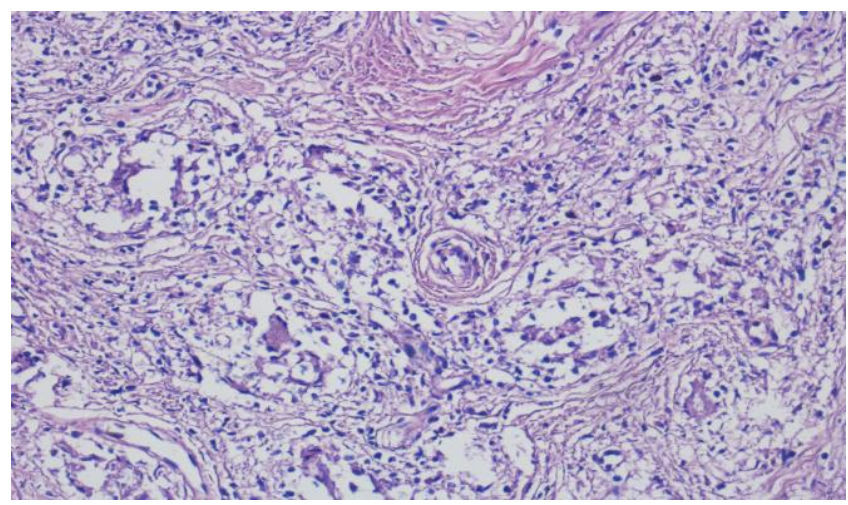

Figure 1: Non-caseifed granulomatous inflammation (H\&E X100)

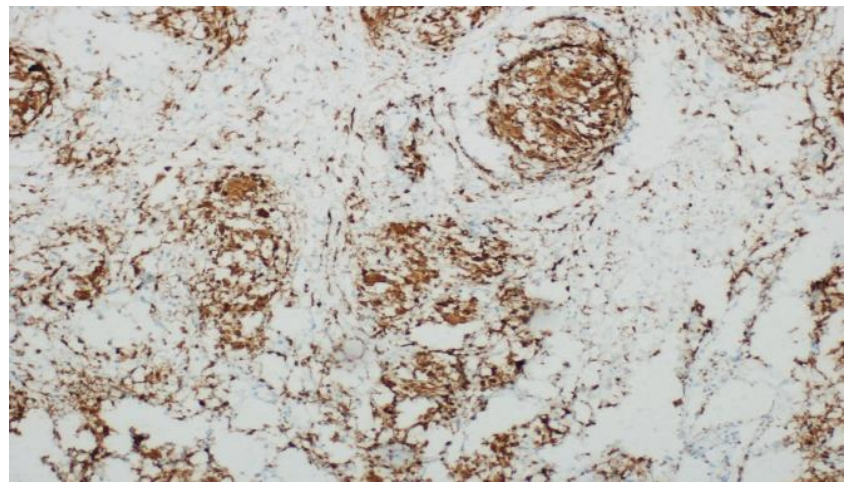

Figure 2: Non-caseifed granulomatous inflammation (H\&E X100)

Case 2: A 39-year-old male was admitted to our urology clinic with penile nodules and nodules were excised for diagnosis. In his dermis biopsy, multiple multi-nuclear giant cells, histiocytes, and granulomas were detected. The patient was admitted to the pulmonary medicine outpatient clinic with shortness of breath, wheezing, and sweating. Bilateral reticular and reticulonodular densities and mediastinal enlargement were seen in PA chest $X$-ray. In $\mathrm{PFT}^{\prime}$ s, FEV1 and FVC were $2.60 \mathrm{~L}(71 \%)$ and $2.85 \mathrm{~L}$ (78\%), respectively and FEV1/FVC 91\%. Biochemical analysis, urine analysis, and erythrocyte sedimentation rate were normal. Fiberoptic bronchoscopy was performed. In bronchoalveolar lavage (BAL) fluid, 40\% lymphocytes, 55\% histiocytes), and 5\% neutrophils were detected. In transbronchial lung biopsy, non-caseified granuloma was seen. Also, the $C D_{4} / C D_{8}$ ratio in the $B A L$ fluid was 6.5. Serum ACE level was $162 \mathrm{U} / \mathrm{L}$. The patient was diagnosed with Stage II pulmonary sarcoidosis and penile sarcoidosis. He was treated with $32 \mathrm{mg} /$ day oral prednisolone to resolve his systemic and pulmonary symptoms. After one month, penile lesions and respiratory symptoms improved with the treatment and serum ACE level decreased to $16.6 \mathrm{U} / \mathrm{L}$. Prednisolone dose was gradually reduced and discontinued at six months.

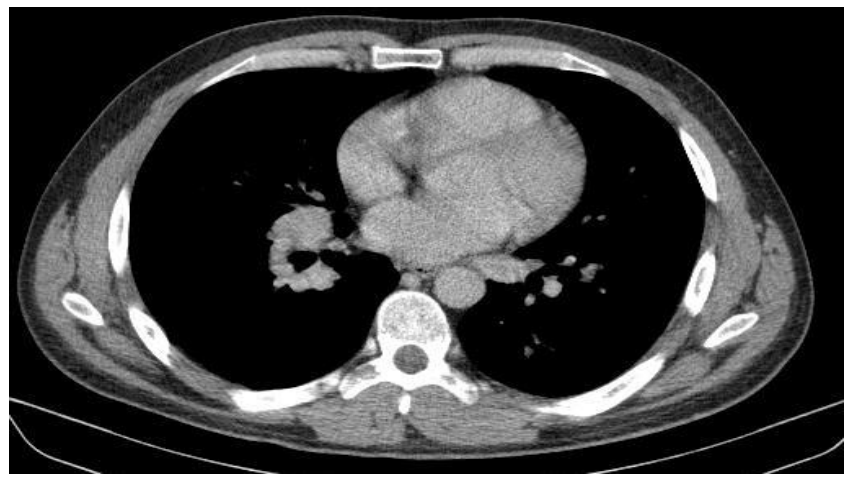

Figure 3: Hiler lymph nodes 


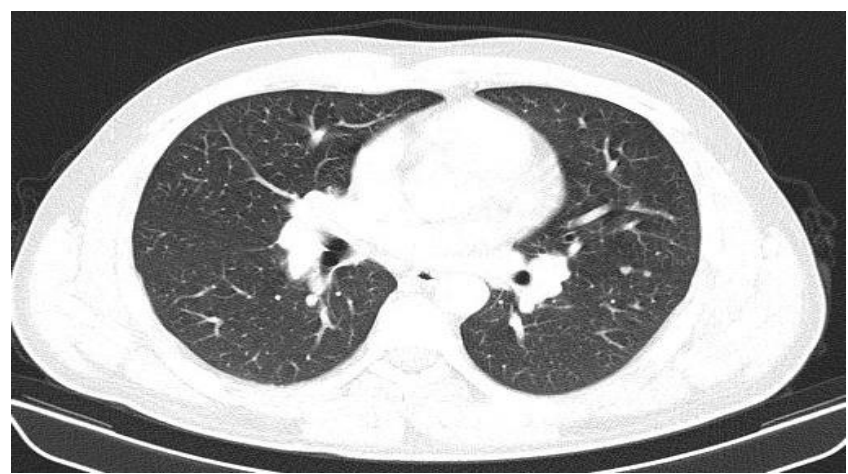

Figure 4: Paranchimal pulmonary nodules

\section{DISCUSSION}

Sarcoidosis is a multi-systemic disease characterized by non-caseified granulomatous inflammation with an unknown etiology (1). Pulmonary involvement was detected $90 \%$ of the cases and the most common symptoms are cough, shortness of breath, and pleuritic chest pain (3). In these cases, mediastinal lymph nodes and several pulmonary milimetric nodules were seen in thoracic computed tomography. The patients may have any systemic complaint; therefore, we do not need to perform systematic screening with gallium-67 scintigraphy or positron emission tomography (4). The most common radiographic findings of thoracic involvement are mediastinal and hilar lymphadenopathy with or without pulmonary parenchymal involvement (5). In our cases, we found mediastinal lymphadenopathy and pulmonary parenchymal nodules, as expected. Extrapulmonary involvements such as cardiovascular system, nervous system, upper respiratory tract, kidneys, spleen, thyroid, gastrointestinal tract, and musculoskeletal involvement is rare $(0.4$ to $5 \%)(3,6)$. Genitourinary tract involvement is much more uncommon $(0.2 \%)$, and usually gives no symptom with a clinically silent presentation $(7,8)$. Clinical course and prognosis of the disease are influenced by ethnic and genetic factors. Extrapulmonary involvement is more common in AfricanAmericans. More than $50 \%$ of genitourinary sarcoidosis is observed in African-American men, while less than 10\% is seen in males (1). Hence, our cases were characterized by a rare involvement. In the literature, it has been reported that male genitourinary sarcoidosis usually involves the scrotum (1). Another interesting feature of our cases is the only penile involvement seen in the genitourinary system.

On the other hand, examination of non-caseous granulomatous inflammation in extrapulmonary organs or tissues is insufficient for the definite diagnosis of sarcoidosis. In these cases, pulmonary assessment should be also performed (9). Therefore, posteroanterior chest X-ray, kidney and liver function tests, urine analysis, electrocardiography, tuberculin skin test, and eye examination are recommended (10). However, our cases had no pathology as assessed by the aforementioned tests and the tuberculin skin test was non-reactive.

In addition, serum ACE level is widely used in the evaluation of patients with sarcoidosis. Serum ACE level is recommended as an indicator of activation of the disease for using in follow-up, but not for diagnosis (11). In the second case, systemic symptoms resolved and serum ACE level decreased, following systemic prednisolone therapy. Based on the presence of mediastinal lymph nodes, increased serum ACE levels, and pathological examination findings of penile nodules, we diagnosed the first case with sarcoidosis. We did not perform any invasive procedure for the diagnosis of mediastinal lymph nodes. In the second case, we performed fiberoptic bronchoscopy, due to respiratory and systemic symptoms. Increased CD4/CD8 ratio, lymphocytic alveolitis, non-caseified granuloma in the transbronchial lung biopsy and increased serum ACE level supported the preliminary diagnosis.

Furthermore, systemic corticosteroids can be used for the treatment of genitourinary sarcoidosis as pulmonary sarcoidosis (10). As the first case did not suffer from any complaints, we planned to follow without systemic treatment. For the second case, we initiated 32 mg/day systemic prednisolone. Penile lesions and respiratory symptoms improved with this treatment.

In conclusion, we emphasize that sarcoidosis is a multisystemic disorder, although the involvement of the genital system is quite rare. Therefore, systemic evaluation of suspected sarcoidosis, as in the other systematic diseases, is of utmost importance. Sarcoidosis should be considered in the differential diagnosis of papules or nodules in the genital area.

\section{CONFLICTS OF INTEREST}

None declared.

\section{AUTHOR CONTRIBUTIONS}

Concept - S.D., E.S.U., F.D., F.T., H.U.K., G.K., K.C.T.; Planning and Design - S.D., E.S.U., F.D., F.T., H.U.K., G.K., K.C.T.; Supervision - S.D., E.S.U., F.D., F.T., H.U.K., G.K., K.C.T.; Funding -; Materials -; Data Collection and/or Processing - S.D.; Analysis and/or Interpretation -; Literature Review -; Writing - S.D., G.K.; Critical Review - K.C.T. 


\section{YAZAR KATKILARI}

Fikir - S.D., E.S.U., F.D., F.T., H.U.K., G.K., K.C.T.; Tasarım ve Dizayn - S.D., E.S.U., F.D., F.T., H.U.K., G.K., K.C.T.; Denetleme - S.D., E.S.U., F.D., F.T., H.U.K., G.K., K.C.T.; Kaynaklar -; Malzemeler -; Veri Toplama ve/veya İşleme - S.D.; Analiz ve/veya Yorum -; Literatür Taraması -; Yazıyı Yazan - S.D., G.K.; Eleştirel İnceleme - K.C.T.

\section{REFERENCES}

1. Statement on sarcoidosis. Joint Statement of the American Thoracic Society (ATS), the European Respiratory Society (ERS) and the World Association of Sarcoidosis and Other Granulomatous Disorders (WASOG) adopted by the ATS Board of Directors and by the ERS Executive Committee, February 1999. Am J Respir Crit Care Med. $1999 ; 160: 736-55$.

2. Hey WD, Shienbaum AJ, Brown GA. Sarcoidosis presenting as an epididymal mass. J Am Osteopath Assoc 2009; 109:609-10.

3. Baughman RP, Teirstein AS, Judson MA, Rossman MD, Yeager $\mathrm{H}$ Jr, Bresnitz EA, et al. Clinical characteristics of patients in a case control study of sarcoidosis. Am J Respir Crit Care Med 2001; 164:1885-9. [CrossRef]

4. Keijsers RG, Grutters JC, Thomeer M, Du Bois RM, Van Buul MM, Lavalaye J, et al. Imaging the inflammatory ac- tivity of sarcoidosis: sensitivity and inter observer agreement of (67)Ga imaging and (18)F-FDG PET. Q J Nucl Med Mol Imaging 2011 ; 55:66-71.

5. McCord MC, Hyman HL. Pulmonary sarcoidosis with the roentgenologic appearances of metastatic neoplasm; a report of two cases. Am J Roentgenol Radium Ther Nucl Med 1952; 67:259- 62.

6. English JC 3rd, Patel PJ, Greer KE. Sarcoidosis. J Am Acad Dermatol 2001; 44:725-43.

7. Svetec DA, Waguespack RL, Sabanegh ES Jr. Intermittent azoospermia associated with epididymal sarcoidosis. Fertil Steril 1998; 70:777-9. [CrossRef]

8. La Rochelle JC, Coogan CL. Urological manifestations of sarcoidosis. J Urol 2012; 187:18-24. [CrossRef]

9. Kıyan E. Sarkoidoz. İç Hastalıkları Derg 2011; 18: 6574.

10. Costabel U, Hunninghake GW. ATS/ERS/WASOG statement on sarcoidosis. Sarcoidosis Statement Committee. American Thoracic Society. European Respiratory Society. World Association for Sarcoidosis and Other Granulomatous Disorders. Eur Respir J 1999; 14:735-7.

11. Canguven O, Balaban M, Selimoglu A, Albayrak S. Corticosteroid therapy improves the outcome of semen analysis in an oligozoospermic patient with epididymal sarcoidosis. Korean J Urol 2013; 54:558-60. [CrossRef] 